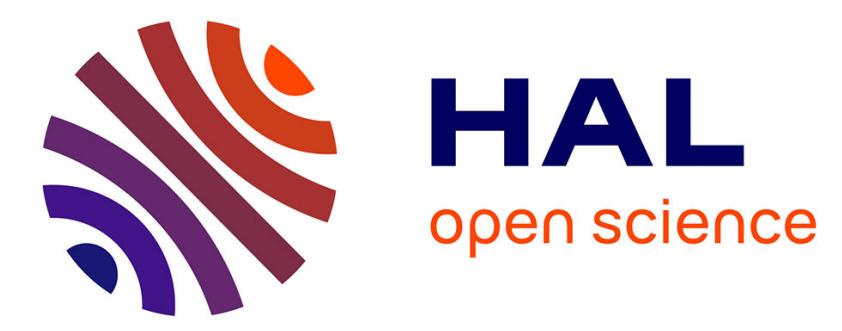

\title{
Optimization of SVM Classifier by k-NN for the Smart Diagnosis of the Short-Circuit and Impedance Faults in a PV Generator
}

\author{
Wail Rezgui, Kinza-Nadia Mouss, Leïla-Hayet Mouss, Mohamed Djamel \\ Mouss, Yassine Amirat, Mohamed Benbouzid
}

\section{To cite this version:}

Wail Rezgui, Kinza-Nadia Mouss, Leïla-Hayet Mouss, Mohamed Djamel Mouss, Yassine Amirat, et al.. Optimization of SVM Classifier by k-NN for the Smart Diagnosis of the Short-Circuit and Impedance Faults in a PV Generator. International Review on Modelling and Simulations (IREMOS), 2014, 7 (5), pp.863-870. 10.15866/iremos.v7i5.3442 . hal-01120840

\section{HAL Id: hal-01120840 \\ https://hal.science/hal-01120840}

Submitted on 26 Feb 2015

HAL is a multi-disciplinary open access archive for the deposit and dissemination of scientific research documents, whether they are published or not. The documents may come from teaching and research institutions in France or abroad, or from public or private research centers.
L'archive ouverte pluridisciplinaire HAL, est destinée au dépôt et à la diffusion de documents scientifiques de niveau recherche, publiés ou non, émanant des établissements d'enseignement et de recherche français ou étrangers, des laboratoires publics ou privés. 


\title{
Optimization of SVM Classifier by k-NN for the Smart Diagnosis of the Short-Circuit and Impedance Faults in a PV Generator
}

\author{
Wail Rezgui ${ }^{1}$, Kinza-Nadia Mouss ${ }^{1}$, Leïla-Hayet Mouss ${ }^{1}$, \\ Mohamed Djamel Mouss ${ }^{1}$, Yassine Amirat ${ }^{2}$ and Mohamed Benbouzid ${ }^{3}$
}

\begin{abstract}
This paper deals with a new algorithm allowing short-circuit and impedance faults smart diagnosis of PV generators. It is based on the use of the SVM technique for the classification of observations not located in its margin, otherwise the proposed algorithm is used a k-NN method.
\end{abstract}

A PV generator database containing observations distributed over classes is used for testing the new algorithm performance, which shows therefore its contribution and its effectiveness in the diagnosis area.

Keywords: Photovoltaic Generator, SVM, k-NN, Short-circuit, Impedance, Smart Diagnosis.

\section{Nomenclature}

Photovoltaic.

Support Vector Machines.

k-Nearest Neighbor.

Class of Observation.

SVM output vector.

Linear function.

Nonlinear mapping function.

Kernel matrix.

Weight vector.

Observations matrix.

New observation.

Class addition.

Lagrange multipliers.

Class number $i$.

$Y$ diagonal.

Transpose.

Number parameters of observation.

Classes number.

Observations number in $X$.

Parameter $j$ of observation $x_{i}$.

Parameter $j$ of new observation $x^{*}$.

Identity matrix.

Tuning parameter for error accepted.

Current.

Voltage.

Power.

Photocurrent.

Current / Voltage of PV cell.

Current / Voltage of PV group.

Current / Voltage of PV module.

Current / Voltage of PV string.

Bypass diode current.

series resistance.

Temperature.

\section{Introduction}

The Earth receives every year a huge amount of energy from the sunlight. Indeed, it receives on average $170 \mathrm{~W} / \mathrm{m}^{2}$ on its surface. However, photovoltaic solar panels are not able to recover all of this energy. Thus, the amount of the usable energy created by the PV solar panels, divided by its radiation energy received is the performance [1]-[2]. Among the major factors that influence the photovoltaic generators performance, the presence of electrical defects such as: short circuit and impedance. It is possible to ensure a good control [3]-[5] and diagnostic [6]-[8] functions of the PV generators, to reduce its maintenance costs and especially increase its productivity.

In this context, the paper objective is the development of an algorithm of a short-circuit and impedance faults smart diagnosis, in a photovoltaic generator. Indeed, the paper contributions are twofold: 1) Development of shortcircuit and impedance detection and localization algorithm, it bases on the analysis of the parameters characterizations, of the faulty components: cells, bypass, and blocking diodes. 2) Development of a smart classifier, to detect the PV generator faults, it used the observations collected from the control system. It is based firstly on the support vector machines (SVM) technique, for the classification of observations not located in its margin [14]-[17], and secondly on the k-NN method in the opposite case [18]-[20].

\section{Classical Diagnosis Algorithm}

The studied generator as it presented in the following Fig. 1 contains five strings connected in parallel. Each 
string contains five modules in series, and ended by blocking diode. Each module contains two groups in series. And finally, each group contains eighteen cells in series, regrouped by one bypass diode in parallel. The proposed diagnosis algorithm is designed for the classical detection and localization, of short-circuit and impedance faults in a PV generator. It contains four main steps:

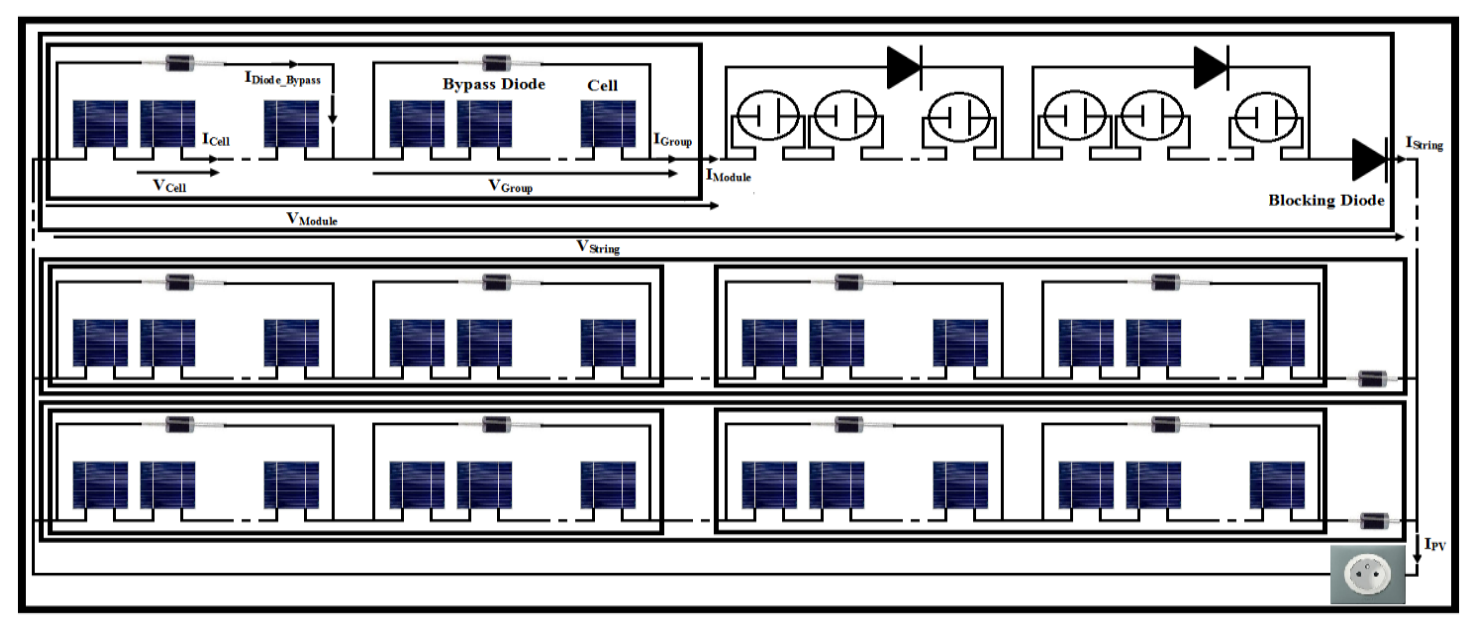

Fig.1 . Photovoltaic generator described

A) Step 1: If a PV generator characteristic is

$$
\left\{\begin{array}{l}
V_{P V}=0 \\
I_{P V}=I_{P V_{-} \text {Short-Circuit }}
\end{array}\right.
$$

means that the generator is short-circuited. But if its characteristic is

$$
\left\{\begin{array}{l}
-V_{P V_{-} \text {Opposite }} \leq V_{P V} \leq V_{P V_{-} \text {Healthy }} \\
-I_{P V_{-} \text {Opposite }} \leq I_{P V}<I_{P V_{-} \text {Short-Circuit }}
\end{array}\right.
$$

indicates the presence of generator components impedance, which can cancel its power, or change its functioning to a receptor.

B) Step2: the PV string is short-circuited if its characteristic is

$$
\left\{\begin{array}{l}
I_{\text {String }}=I_{\text {String_Short-Circuit }} \\
V_{\text {String }}=0
\end{array}\right.
$$

But, if its characteristic is

$$
\left\{\begin{array}{l}
V_{\text {String }}=V_{\text {String_Opposite }} \\
I_{\text {String_Cells }}=0 \\
I_{\text {String }}=I_{\text {String_Opposite }}<0 \\
I_{\text {String_PH }}=0
\end{array}\right.
$$

indicates the presence of blocking diode short circuited. Also, if its characteristic is

$$
\left\{\begin{array}{l}
I_{\text {String }} \geq I_{\text {String_Healthy }} \\
I_{P H_{-} \text {String }} \neq 0 \\
I_{\text {String_Opposite }}=0 \\
V_{\text {String }}<V_{\text {String_Healthy }} \\
\sum V_{\text {String_Modules }}=V_{\text {String }}
\end{array}\right.
$$

means the presence of at least one module impedance. Or, if its characteristic is

$$
\left\{\begin{array}{l}
I_{\text {String_Cells }}=0 \\
I_{\text {String_PH }}=0 \\
I_{\text {String }}=I_{\text {String_Opposite }}<0 \\
V_{\text {String }}=V_{\text {String_Opposite }}
\end{array}\right.
$$

indicates the presence of default blocking diode impedance.

C) Step3: A PV module is short-circuited if its characteristic is

$$
\left\{\begin{array}{l}
I_{\text {Module }}=I_{\text {Module_Short-Circuit }} \\
V_{\text {Module }}=0
\end{array}\right.
$$

This situation means that all its groups are shortcircuited. But, if its characteristic is

$$
\left\{\begin{array}{l}
I_{\text {Module_Groups }} \geq I_{\text {Module_Healthy }} \\
I_{P H_{-} \text {Module }} \neq 0 \\
I_{\text {Module_Opposite }}=0 \\
V_{\text {Module }} \leq V_{\text {Module_Healthy }} \\
\sum V_{\text {Module_Groups }}=V_{\text {Module }}
\end{array}\right.
$$

means the presence of least one group impedance. 
D) Step4: if a PV group characteristic is

$$
\left\{\begin{array}{l}
I_{\text {Group }}=I_{\text {Group_Short-Circuit }} \\
V_{\text {Group }}=0
\end{array}\right.
$$

means that the group is short-circuited. Also, if its characteristic is

$$
\left\{\begin{array}{l}
I_{\text {Group }}=I_{\text {Group_Cells_Short-Circuit }}+I_{\text {Bypass_Diode }_{-}} \\
V_{\text {Group }}=0
\end{array}\right.
$$

indicates the presence of all the group cells are shortcircuited. In addition, if its characteristic is

$$
\left\{\begin{array}{l}
I_{\text {Group }}=I_{\text {Group_Cells_Healthy }}+I_{\text {Bypass_Diode }} \\
V_{\text {Group }}=0
\end{array}\right.
$$

means that the group is connected by a bypass diode short-circuited. But, if its characteristic is

$$
\left\{\begin{array}{l}
I_{\text {Group_Cells }}=0 \\
I_{\text {Group }}=I_{\text {String }} \\
I_{\text {PH_Group }} \neq 0 \\
I_{\text {Group_Opposite }}=0 \\
V_{\text {Group }}=0
\end{array}\right.
$$

indicates the default all the group cells are impedances. Or, if its characteristic is

$$
\left\{\begin{array}{l}
I_{\text {Group }}>I_{\text {Group_Healthy }} \\
I_{P H_{-} \text {Group }} \neq 0 \\
I_{\text {Group_Opposite }}=0 \\
V_{\text {Group }}=V_{\text {Group_Healthy }}
\end{array}\right.
$$

means the presence of bypass diode impedance.

\section{Intelligent Diagnosis Algorithm}

\section{III.1. SVM algorithm}

This technique is a method of two-class classification, which attempts to separate the positive examples from which are negative, in the same space.

The method seeks the hyper-plane that separates the positive examples from which are negative, by ensuring that the margin between the nearest of the positive and negative examples is maximum. This ensures a generalization of the principle, as new examples may not be too similar to those used to find the hyper-plane, but be located on one side or the other of the border.

The advantage of this method is the selection of support vectors, which represent the discriminate vectors by which the hyper-plane is determined. The examples used in the search of the hyper-plane are no longer needed, and only those supports vectors are used to assign a new case, which can be seen as an advantage for this method. This technique consist mainly two steps:

\section{1) Step1: construct the SVM Classifier}

The objective is to construct a function $f$, which for each input value $x$ in a set $\mathbb{R}^{d}$ will match an output value $\mathrm{y} \in\{-1,1\}$. The following model describes the learning function $f$ in the linear case and also in the non-linearly, but after changing the data space to another with a larger dimension, by the nonlinear mapping function $\Phi$.

$$
f(x)=\left[\begin{array}{l}
\text { If the problem is linear separable } \\
\operatorname{sign}\left(\left\langle w_{c, \complement(c)} \cdot x\right\rangle+b_{c, \complement(c)}\right) \\
\text { Else } \\
\operatorname{sign}\left(\left\langle w_{c, \complement(c)} \cdot \phi(x)\right\rangle+b_{c, \complement(c)}\right) \\
\text { End }
\end{array}\right]
$$

2) Step2: determining the Hyper-Plane

In the new space data, there are many hyper-planes separating, the best is which maximizes the margin between its location and the support vectors. The following model describes the hyper-plane optimal resulting by the linear programming to found the parameters of the $f$ function.

$$
\begin{aligned}
& f(x)= \\
& {\left[\begin{array}{l}
\text { If the problem is linear separable } \\
\operatorname{sign}\left(\alpha_{c, \mathcal{C}(c)}^{T} X x+\frac{1}{y_{i}}\left(1-\alpha_{c, \complement(c)}\left(D K D+\frac{1}{J} I^{\prime}\right)\right)\right) \\
\text { Else } \\
\operatorname{sign}\left(K\left(x, X^{T}\right) D \alpha_{c, \complement(c)}+\frac{1}{y_{i}}\left(1-\alpha_{c, \complement(c)}\left(\begin{array}{c}
D K D \\
+\frac{1}{J} I^{\prime}
\end{array}\right)\right)\right. \\
\text { End }
\end{array}\right]}
\end{aligned}
$$

SVM and like all classification techniques, it has some drawbacks mainly: 1) the binary classification which need to solved the problem by a set of equations, each one presents a classifier between a class and its complement, except classes already processed. 2) The classification of new examples which are located in the SVM margin, and especially if this margin is not well maximized. In this paper we propose for the latter problem as a solution, using the classical method k-NN.

\section{III.2. $k$-NN method}

This is a very simple and straightforward approach. It does not require learning, but simply storing training data. Its principle is as follows:

1) Step1: $k-N N$ compares the new example $x^{*}$ of unknown class, to the all oldest examples in its databases $X$. 


$$
X^{t+1}=\left[\begin{array}{c}
\text { Dis }\left[x_{1}-x^{*}\right] \\
\operatorname{Dis}\left[x_{2}-x^{*}\right] \\
\vdots \\
\text { Dis }\left[x_{m}-x^{*}\right]
\end{array}\right]
$$

With

$m$ : examples number of $X^{t}$.

Dis: distance.

2) Step2: $k-N N$ chooses for this new example the majority class among its $k$ nearest neighbors (so it can be cumbersome for large databases) as defined by a selected distance.

$$
x^{*} \in \text { Class of Observations of Dis minimum }
$$

\section{The Proposed Smart Algorithm}

Our contribution in this section is to develop a mathematical model bases on the tools presented above. It is able to make a smart classification of a PV generator defects, aims to increase the classification rate, and at the same time to minimize the classification error rate. In this proposed model, we used for the activation function of SVM the Gaussian type, and for the k-NN method using the Euclidean distance between the gravity centers of database observations.

$$
\begin{aligned}
& \text { If the problem is linear separable } \\
& {\left[\operatorname{sign}\left(\alpha_{c_{1}, C\left(c_{1}\right)}^{T} X x^{*}+\frac{1}{y_{i}}\left(1-\alpha_{c_{1}, C\left(c_{1}\right)}\left(D K D+\frac{1}{J} I^{\prime}\right)\right)\right)\right.} \\
& \operatorname{sign}\left(\alpha_{c_{M-1}, c_{M}}^{T} X x^{*}+\frac{1}{y_{i}}\left(1-\alpha_{c_{M-1}, c_{M}}\left(D K D+\frac{1}{J} I^{\prime}\right)\right)\right) \\
& f(x *)=(1-\xi) \text { Else } \\
& {\left[\operatorname{sign}\left(K\left(x^{*}, X^{T}\right) D \alpha_{c_{1}, \complement\left(c_{1}\right)}+\frac{1}{y_{i}}\left(1-\alpha_{c_{1}, \mathcal{C}\left(c_{1}\right)}\left(D K D+\frac{1}{J} I^{\prime}\right)\right)\right)\right.} \\
& \operatorname{sign}\left(K\left(x^{*}, X^{T}\right) D \alpha_{c_{M-1}, c_{M}}+\frac{1}{y_{i}}\left(1-\alpha_{c_{M-1}, c_{M}}\left(D K D+\frac{1}{J} I^{\prime}\right)\right)\right) \\
& \text { End } \\
& +\xi * C O\left[\operatorname{index}\left[\min \left[\begin{array}{c}
\frac{1}{N} \sum_{j=1}^{N}\left|x_{j 1}-x_{j}^{*}\right| \\
\frac{1}{N} \sum_{j=1}^{N}\left|x_{j 2}-x_{j}^{*}\right| \\
\vdots \\
\frac{1}{N} \sum_{j=1}^{N}\left|x_{j m}-x_{j}^{*}\right|
\end{array}\right]\right)\right.
\end{aligned}
$$

Where $\xi=1$ if $x$ is in the margin of the SVM classifier, else $\xi=0$.

\section{Simulations Results}

\section{IV.1. Faulted PV Generator Characterization}

The main simulation results of the diagnostic algorithm are shown by Figs. 2 to 4 .

1) Fig. 2 presents the evolution of the power supplied by a generator contains cells short-circuit and impedance. It therefore shows that the power of a PV generator is reduced in proportion to the increase in the numbers of its defective cells.

2) Fig. 3 presents the influence of short-circuited and impedance faults at the bypass diodes, on the functioning of a photovoltaic generator. It shows that the bypass diode short-circuit defect $a$ ) affects the group voltage, but the current remains independent, unless all its string groups are failed. By const, it shows that the impedance defect $b$ ) has no influence on the characterization of a faulty string, which contains at least one good group, $c$ ) else the power of the generator increases, proportionally to the increase in the number of strings which all its groups are defective, because its currents are increases, until reaches its short-circuit value.

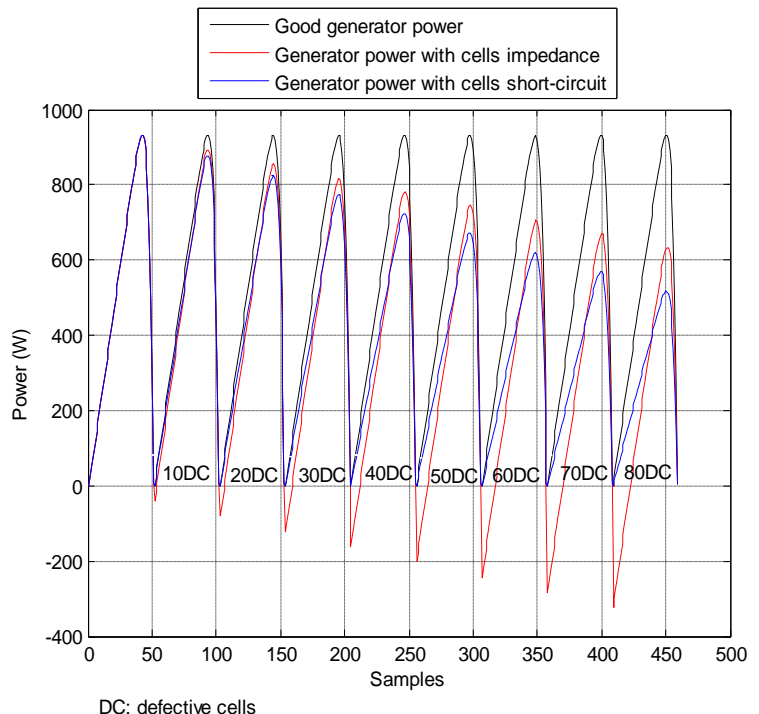

Fig2. Short-circuit and impedance cells influence on the PV generator operation.

3) Fig. 4 presents the influence of the blocking diode short-circuited and impedance faults, on the functioning of a photovoltaic generator. It shows that these defects can make a remarkable deterioration in the power supplied by a generator, because the blocking diode short circuit default, with another defect which can reduce its 
string voltage, and also for the blocking diode impedance default which may reduce the voltage of its string, so these two situations can create the reverse current in its strings, and therefore change its characterizations to a receivers in the absence of the photocurrent, or becomes as open circuit in the opposite case.

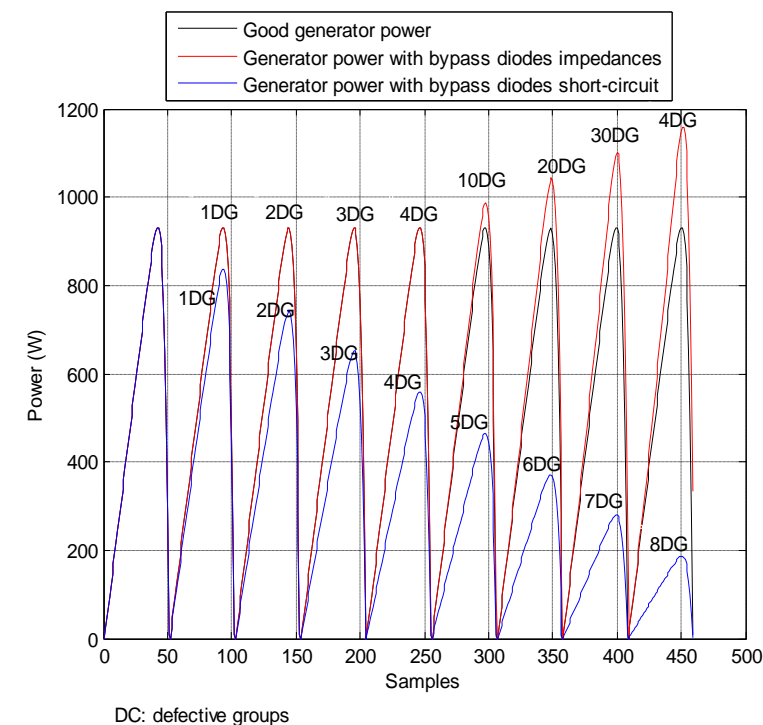

Fig3. Short-circuit and impedance bypass diodes influence on the PV generator operation.

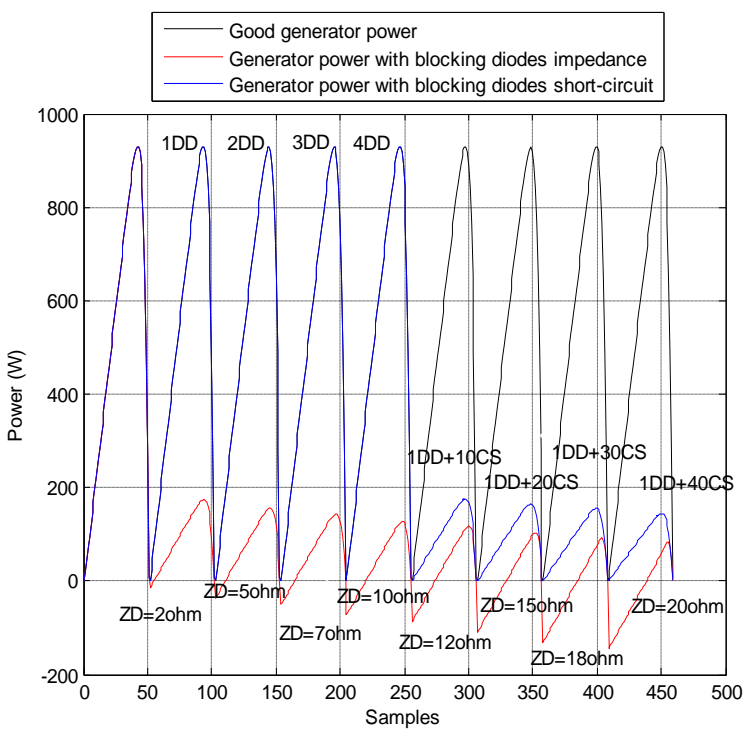

ZD: blocking diode impedance, DD: defective blocking diode, CS: cell short circuit

Fig4. Short-circuit and impedance blocking diodes influence on the PV generator operation.

\section{IV.2. Smart Algorithm Tests}

The proposed smart fault detection and diagnosis algorithm is tested using a PV generator database containing observations (Tab. 1) distributed over classes (Tab. 2) [24-25]. For that purposes, three indicators are used: the rate of good classified observations (Figs. 5-6), the computation time to classify any new observation (Fig. 7), and finally the classification error rate (Figs. 89).

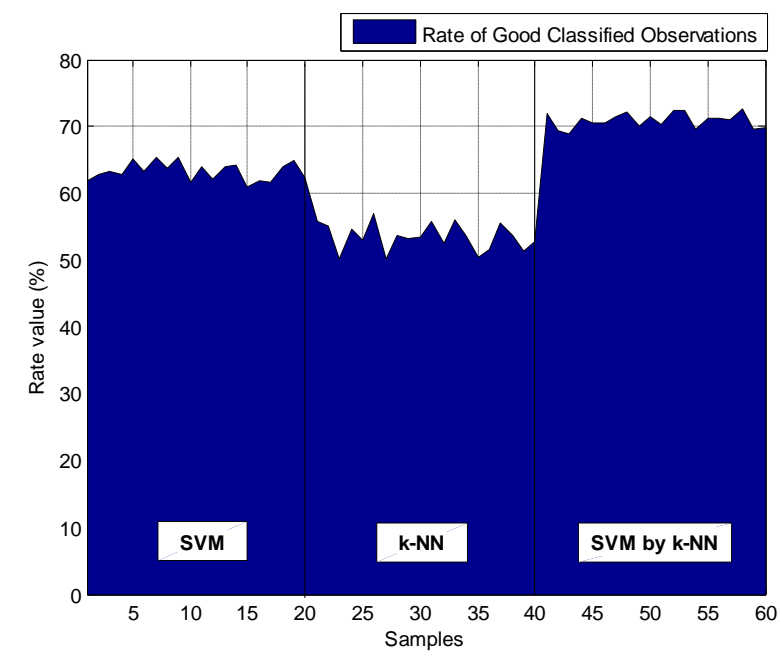

Fig. 5. Observation classification rate $v s$ tools.

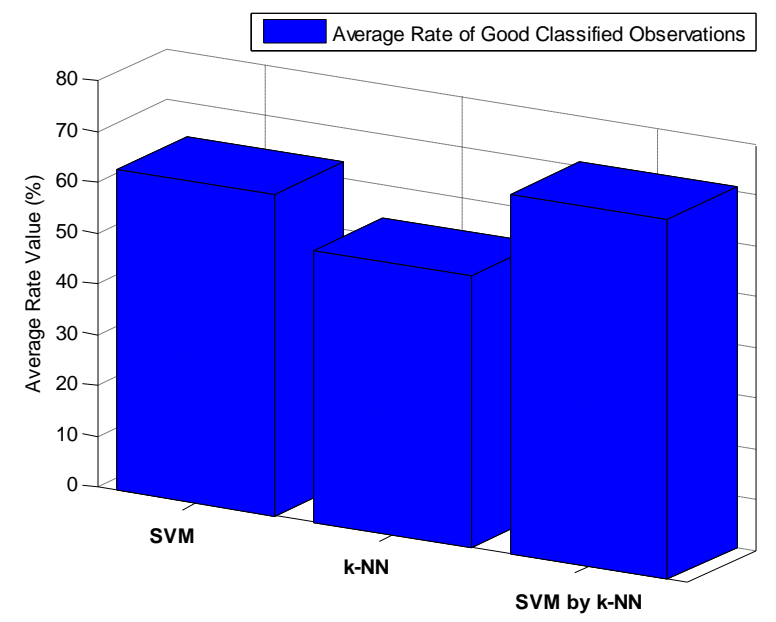

Fig. 6. Observation classification average rate $v s$ tools.

\begin{tabular}{|c|c|c|c|c|}
\hline Class & $\begin{array}{l}\text { normal } \\
\text { operation }\end{array}$ & $\begin{array}{l}\text { defective } \\
\text { cells }\end{array}$ & $\begin{array}{l}\text { defective } \\
\text { bypass } \\
\text { diodes }\end{array}$ & $\begin{array}{l}\text { defective } \\
\text { blocking } \\
\text { diodes }\end{array}$ \\
\hline $\begin{array}{l}\text { Number } \\
\text { observations ' } X \text {, }\end{array}$ & 1632 & 1632 & 1632 & 1632 \\
\hline \multicolumn{5}{|c|}{ TABLE.2. OBSERVATION PARAMETERS } \\
\hline
\end{tabular}

Each observation is presented by its center of gravity ' $x$ '.

The achieved results (Figs. 5-6) show that the rate of good classified observations is

TABLE.3. RATE OF GOOD CLASSIFIED OBSERVATIONS

\begin{tabular}{|l|l|l|l|}
\hline Classifier & SVM & k-NN & SVM_k-NN \\
\hline Rate $(\%)$ & 60 to 69.9 & 50 to 53.5 & 68 to $75.8 \%$ \\
\hline
\end{tabular}

The achieved results (Fig. 7) show that the computation time is

TABLE.4. NeW OBSERVATION CLASSIFICATION ELAPSED TIME

\begin{tabular}{|l|l|l|l|}
\hline Classifier & SVM & k-NN & SVM_k-NN \\
\hline Computation Time (second) & 5.5 to 7 & 2 to 3 & 5 to 10 \\
\hline
\end{tabular}

The achieved results (Figs. 8-9) show that classification error rate is 
Tab.5. Classification Error Rate

\begin{tabular}{|l|l|l|l|}
\hline Classifier & SVM & k-NN & SVM_k-NN \\
\hline Rate $(\%)$ & 0.8 to 0.9 & 1.5 to 2 & 0.36 to 0.55 \\
\hline
\end{tabular}

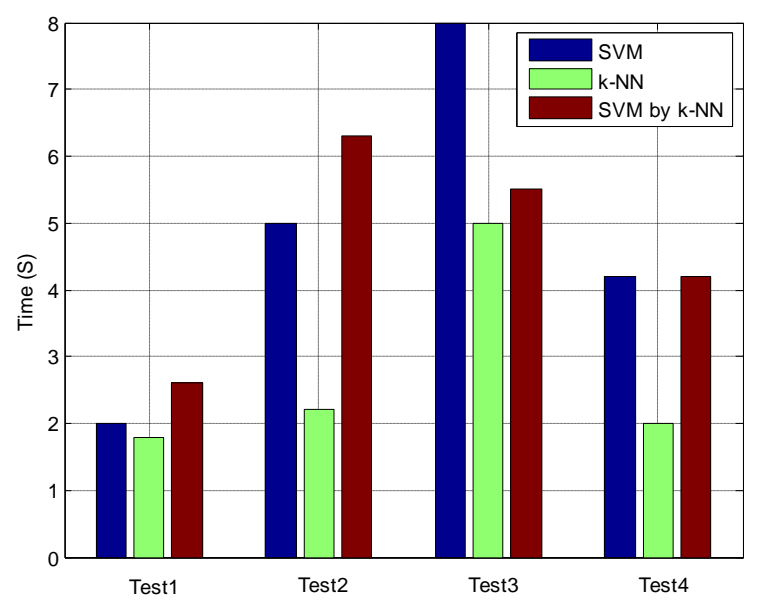

Fig. 7. New observation classification elapsed time $v s$ tools.

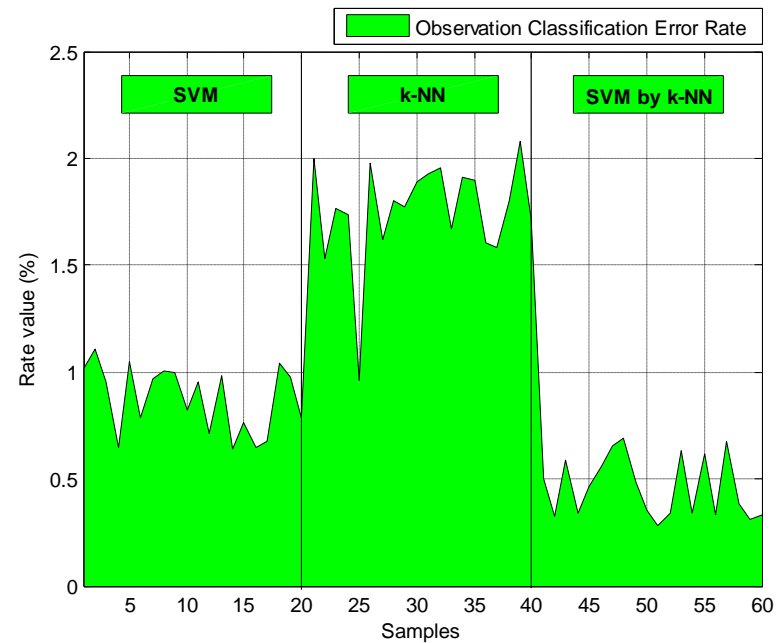

Fig. 8. Observation classification error rate $v s$ tools.

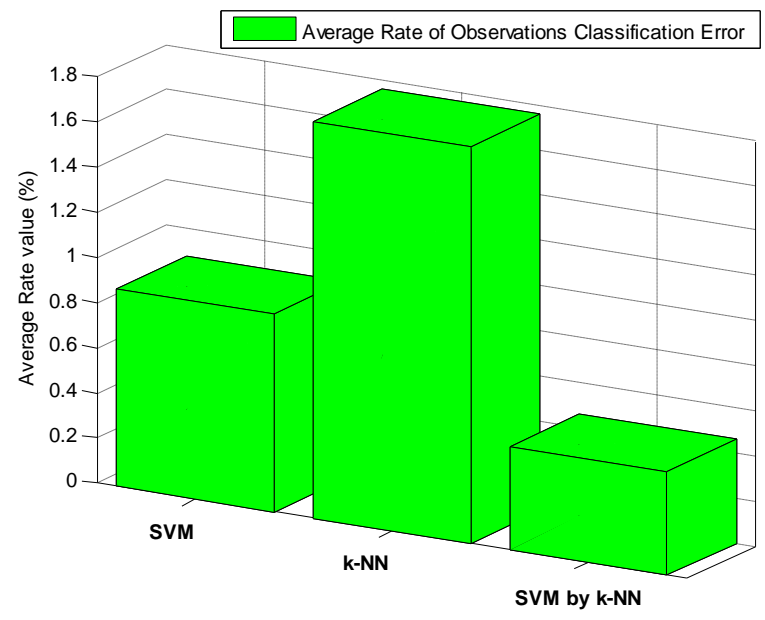

Fig. 9. Observation classification error average rate $v s$ tools.
The analysis of the above achieved results shows that the proposed new classifier has a high classification rate, with a low error rate, but it is a little bit time consuming, due the mathematical computations.

\section{Conclusion}

This paper dealt with a new smart algorithm allowing short-circuit and impedance detection and diagnosis in PV generators. It is based on the optimization of SVM classifier, firstly by solving a set of equations as a solution to the problem of multi-class. And secondly by $\mathrm{k}-\mathrm{NN}$ as a solution to the classification of observations, which located on the SVM classifier itself and its margin.

The new algorithm proposed in this paper shows its specific features: a high classification rate with a low error rate. But, it is a little bit time consuming due the mathematical computations, which necessities to more improvement in the future work as perspective.

\section{References}

[1] R. Iannone, S. Miranda, S. Riemma, G. Spagnuolo, An Integrated Approach to the Simulation/optimization of Grid-connected Photovoltaic Systems: the Rational Choice of Components, International Review of Electrical Engineering (IREE), Vol. 7, $\mathrm{n}$. 3, pp. 4596-4606, June 2012.

[2] Y. Riffonneau, S. Bacha, F. Barruel, Y. Baghzouz, E. Zamaï, Optimal Reactive Supervision of Grid Connected PV Systems with Batteries in Real Conditions, International Review of Electrical Engineering (IREE), Vol. 7. n. 3, pp. 4607-4615, June 2012.

[3] R. M. Essefi, M. Souissi, H. H. Abdallah, Current Control Strategy for Grid Connected Photovoltaic Inverter via LCL Filter, International Review on Modelling and Simulations (IREMOS), Vol 6, n. 5, pp. 1426-1434, 2013.

[4] M. Guisser, M. Aboulfatah, E. Abdelmounim, A. El jouni, Nonlinear MPPT Controller for Photovoltaic Pumping System Based on Robust Integral Backstepping Approach, International Review on Modelling and Simulations (IREMOS), Vol 7, n. 3, pp. 481-488, 2014.

[5] R. M. Essefi, M. Souissi, H. H. Abdallah, Intelligent Approach to Maximum Power Point Tracking Control Strategy for Photovoltaic Generation Systems, International Review on Modelling and Simulations (IREMOS), Vol 7, n. 2, pp. 287-297, 2014.

[6] W. Rezgui, L. H. Mouss, M. D. Mouss, O. KADRI and A. DISSA, Electrical faults detection for the intelligent diagnosis of a photovoltaic generator, Journal of Electrical Engineering, Vol. 14, Issue. 1, pp. 77-84, March 2014.

[7] W. Rezgui, L.H. Mouss, N.K. Mouss, M.D. Mouss and M.E.H. Benbouzid, A smart algorithm for the diagnosis of short-circuit faults in a photovoltaic generator, in Proceedings of the 2014 IEEE ICGE, Sfax (Tunisia), pp. 1-5, March 2014.

[8] W. Rezgui, L.H. Mouss, N.K. Mouss, M.D. Mouss, Y. Amirat and M.E.H. Benbouzid, Development of a smart algorithm for the prognosis and the diagnosis of the short circuit and the reversed polarity faults in a photovoltaic generator, in Proceedings of the 2014 ICIEM, Batna (Algeria), May 2014.

[9] B-K. Kang, S-T. Kim, S-H. Bae, J-W. Park, Diagnosis of Output Power Lowering in a PV Array by Using the Kalman-Filter Algorithm, IEEE Transactions on Energy Conversion, Vol. 27, Issue. 4, pp. 885 - 894, Dec. 2012.

[10] Y. Hirata, S. Noro, T. Aoki, S. Miyazawa, Diagnosis photovoltaic failure by simple function method to acquire $\mathrm{I}-\mathrm{V}$ curve of photovoltaic modules string, in the proceeding of 2012 
IEEE PVSC ( $38^{\text {th }}$ Photovoltaic Specialists Conference), pp. 001340 - 001343, Austin, TX, 3-8 June 2012.

[11] M. Gonzalez, B. Raison, S. Bacha, L. Bun, Fault diagnosis in a grid-connected photovoltaic system by applying a signal approach, in the proceeding of 2011 IEEE IECON (37 ${ }^{\text {th }}$ Annual Conference on IEEE Industrial Electronics Society), pp. 1354 1359, Melbourne, VIC, 7-10 Nov. 2011.

[12] T. Jianeng, Z. Yongqiang, W. Wenshan, Fault diagnosis method and simulation analysis for photovoltaic array, in the proceeding of 2011 IEEE ICECE (International Conference on Electrical and Control Engineering), pp. 1569 - 1573, Yichang, 16-18 Sept. 2011.

[13] X. Xu, H. Wang, Y. Zuo, Method for Diagnosing Photovoltaic Array Fault in Solar Photovoltaic System, in the proceeding of 2011 IEEE APPEEC (Asia-Pacific Power and Energy Engineering Conference), pp. 1 - 5,.Wuhan, 25-28 March 2011.

[14] X. Yang, F. Jiang, H. Liu, Short-term solar radiation prediction based on SVM with similar data, in the proceeding of 2013 IEEE $R P G\left(2^{\text {nd }}\right.$ IET Renewable Power Generation Conference), pp. 1 4, Beijing, 9-11 Sept. 2013.

[15] S. Weckx, C. Gonzalez, T-D. Rybel, J. Driesen, LS-SVM-based on-load tap changer control for distribution networks with rooftop PV's, in the proceeding of 2013 IEEE ISGT EUROPE $\left(4^{\text {th }}\right.$ IEEE/PES Innovative Smart Grid Technologies Europe), pp. 1 - 5, Lyngby, 6-9 Oct. 2013.

[16] L. Peng, F. Liqiang, X. Peng, J. Jinxing, J. Zhang, HHT based on the LS-SVM and its application in the voltage flicker and harmonic detection of microgrid, in the proceeding of 2011 IEEE $D R P T \quad\left(4^{\text {th }}\right.$ International Conference on Electric Utility Deregulation and Restructuring and Power Technologies), pp. 1722 - 1726, Weihai, Shandong, 6-9 July 2011.

[17] C. Runqing, C. Haoyong, L. Runge, J. Xiaoming, L. Huanghuang, Distributed generation planning in distribution network based on hybrid intelligent algorithm by SVM-MOPSO, in the proceeding of 2013 IEEE APPEEC (PES Asia-Pacific Power and Energy Engineering Conference), pp. 1 - 6, Kowloon, 8-11 Dec. 2013.

[18] A. Bouguerne, A. Lebaroud, A. Medoued, A. Boukadoum, Classification of induction machine faults by K-nearest neighbor, in the proceeding of 2011 IEEE ELECO $\left(7^{\text {th }}\right.$ International Conference on Electrical and Electronics Engineering), pp. I-363 - I-366, Bursa, 1-4 Dec. 2011

[19] M. Luo, Y. Zheng, S. Liu, Data-based fault-tolerant control of the semiconductor manufacturing process based on K-nearest neighbor nonparametric regression, in the proceeding of 2012 IEEE WCICA $\left(10^{\text {th }}\right.$ World Congress on Intelligent Control and Automation), pp. 3008 - 3012,. Beijing, 6-8 July 2012.

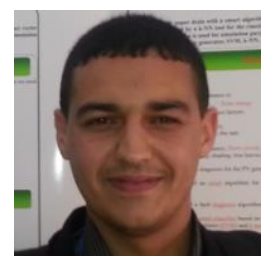

Wail REZGUI was born in N'gaous, Algeria, in 1987. He received his license in industrial engineering, industrial computer and Production option from Batna university between 2005- 2008, and his Master of Industrial Engineering, Industrial Computer and Production option, from university of Batna between 2008-2010. And finally he is currently pursuing $\mathrm{Ph} . \mathrm{D}$. studies on Industrial Engineering at the University of Batna.

Mr. REZGUI is member in the Automation and Manufacturing laboratory (LAP). His current research interests include diagnosis of photovoltaic systems using artificial intelligence techniques.
[20] G. Verdier, A. Ferreira, Fault detection with an adaptive distance for the k-Nearest neighbors rule, in the proceeding of 2009 IEEE ICCIE (International Conference on Computers \& Industrial Engineering), pp. 1273 - 1278, Troyes, 6-9 July 2009.

[21] O. Gana, C. Vasar, M. Babescu, A. Vartosu, PV control system based on short-circuit current, in the proceeding of 2013 IEEE SACI $\left(8^{\text {th }}\right.$ International Symposium on Applied Computational Intelligence and Informatics), pp. 387 - 390, Timisoara, Romania, 23-25 May 2013.

[22] S. Phuttapatimok, A. Sangswang, K. Kirtikara, Effects on short circuit level of PV grid-connected systems under unintentional islanding, in the proceeding of 2008 IEEE ICSET (International Conference on Sustainable Energy Technologies), pp. 928 - 932, Singapore, 24-27 Nov. 2008.

[23] W. Rezgui, L.H. Mouss, N.K. Mouss, M.D. Mouss and M.E.H Benbouzid, A Regression Algorithm for the Smart Prognosis of a Reversed Polarity Fault in a Photovoltaic Generator, in Proceedings of the 2014 IEEE ICGE, Sfax (Tunisia), pp. 1-5, March 2014.

[24] W. Rezgui, L.H. Mouss, M.D Mouss, Modeling of a photovoltaic field in malfunctioning, in Proceedings of the 2013 IEEE CoDIT (International Conference on Control, Decision and Information Technologies), Hammamet (Tunisia), pp. 788 - 793, 6-8 May 2013.

[25] W. Rezgui, L.H. Mouss, N.K. Mouss, M.D. Mouss, Y. Amirat and M.E.H. Benbouzid, Electrical faults modeling of the photovoltaic generator, International Review on Modelling and Simulations (IREMOS), Vol.7, №2, pp. 245-257, May 2014

[26] X-F. Xiong, W. Zheng, K. Chen, Z-J. Shen, Identification Approach in Modeling a Photovoltaic Grid-Tie Inverter, International Review of Electrical Engineering (IREE), Vol. 7. n. 3 , pp. 4575-4584, June 2012.

[27] Mohamed Mostefai, Abdellah Miloudi, Yahia Miloud, An Intelligent Maximum Power Point Tracker for Photovoltaic Systems Based on Neural Network, International Review on Modelling and Simulations (IREMOS), Vol. 6, n. 5, pp. 1477 1481, 2013.

\section{Authors' information}

${ }^{1}$ First author affiliation: Laboratory of Automation and Manufacturing, Batna Univerity, Rue Chahid Boukhlouf Batna Algeria.

${ }^{2}$ Second author affiliation: ISEN Brest, EA 4324 LBMS, Brest, France.

${ }^{3}$ Third author affiliation: University of Brest, EA 4325 LBMS, Rue de Kergoat, CS 93837, 29238 Brest Cedex 03, France.

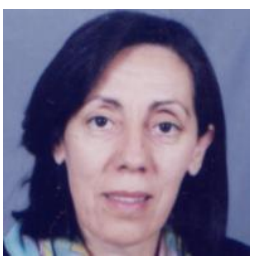

Leila Hayet Mouss was born in Batna, Algeria, in 1954. She received the B.Sc. degree in Electrical Engineering, in 1979, from the National Polytechnic School of Algiers, Algeria; the M.Sc. degree in Electrical and Computer Engineering, in 1982, from the ENSERB, France; and finally the Ph.D. degree also in Electrical and Computer Engineering, in 1985, Bordeaux University, France.

After graduation, she joined the University of Batna, Algeria, where she is an Associate Professor of Electrical and Computer Engineering. Pr. Mouss is a member of New York Science Academy. She is the head of Automatic and Computer Integrated Manufacturing Laboratory. Pr Mouss current research interests include industrial Diagnosis of production system using the artificial intelligence techniques in the LAP Lab (Laboratory of Automation and Manufacturing) at Batna, Algeria. 


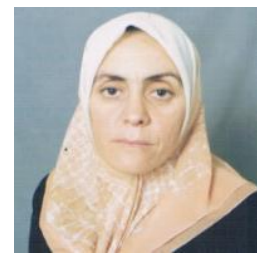

Kinza Nadia MOUSS was born in Batna, Algeria, in 1960. She received the B.Sc. degree in Electrical Engineering, in 1983, from the National Polytechnic School of Algiers, Algeria; the M.Sc. degree in Electrical and Computer Engineering, in 1984, from the ENSERB, France; and finally the Ph.D. degree also in Electrical and Computer Engineering, in 1986, Bordeaux University, France.

After graduation, she joined the University of Batna, Algeria, where she is a Professor of Electrical and Computer Engineering. Pr. Mouss is the head of Computer Integrated Manufacturing and supply chain management group. Pr. Mouss current research interests include industrial Supply Chain Management, Production system and Computer Integrated Manufacturing.

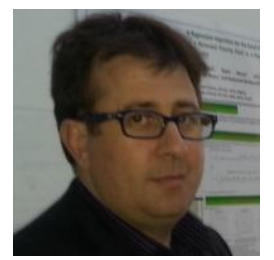

Yassine Amirat was born in Annaba, Algeria, in 1970. He received the B.Sc. and M.Sc. degrees in electrical engineering from the University of Annaba, Annaba, in 1994 and 1997, respectively. $\mathrm{He}$ is currently working toward the Ph.D. degree in wind turbine condition monitoring at the University of Brest, Brest, France. He is currently a Lecturer with the High Institute of Electronics and Numeric, Brest. His current research interests are the condition monitoring and the control of electrical drives and power electronics.

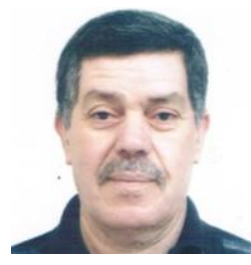

Mohamed Djamel MOUSS was born in Batna, Algeria, in 1956. He received the B.Sc degree in Electrical Engineering, in 1982, from the National Polytechnic School of Algiers, Algiers, Algeria; the M.Sc. degree in Industrial Electricity and the Ph.D degree in Industrial Engineering, both from the University of Batna, Batna, Algeria, in 1989 and 2006, respectively; and the University Habilitation degree from the University of Batna, Batna, Algeria, in 2008.

After graduation, he joined the University of Batna, Batna, Algeria, where he is an Associate Professor of Electrical and Computer Engineering. Dr. Mouss is the leader of the $\mathrm{S}^{3}$ team (Sûreté, Supervision, Surveillance) of the Automatic and Computer Integrated Manufacturing Laboratory (LAP). His current research interests include diagnosis of industrial production system using artificial intelligence techniques.

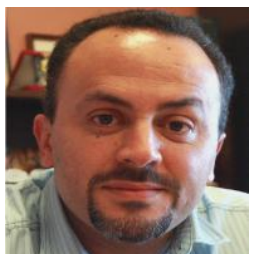

Mohamed El Hachemi Benbouzid was born in Batna, Algeria, in 1968. He received the B.Sc. degree in electrical engineering from the University of Batna, Batna, Algeria, in 1990, the M.Sc. and Ph.D. degrees in electrical and computer engineering from the National Polytechnic Institute of Grenoble, Grenoble, France, in 1991 and 1994, respectively, and the Habilitation à Diriger des Recherches degree from the University of Picardie "Jules Verne," Amiens, France, in 2000.

After receiving the Ph.D. degree, he joined the Professional Institute of Amiens, University of Picardie "Jules Verne," where he was an Associate Professor of electrical and computer engineering. Since September 2004, he has been with the Institut Universitaire de Technologie of Brest, University of Brest, Brest, France, where he is a Professor of electrical engineering. His main research interests and experience include analysis, design, and control of electric machines, variable-speed drives for traction, propulsion, and renewable energy applications, and fault diagnosis of electric machines.

Prof. Benbouzid is an IEEE Senior Member. He is the Editor-inChief of the International Journal on Energy Conversion (IRECON). He is also an Associate Editor of the IEEE TRANSACTIONS ON ENERGY CONVERSION, the IEEE TRANSACTIONS ON INDUSTRIAL ELECTRONICS, the IEEE TRANSACTIONS ON SUSTAINABle ENERGY, and the IEEE TRANSACTIONS ON Vehicular TEChNOLOGY. He was an Associate Editor of the IEEE/ASME TRANSACTIONS ON MECHATRONICS from 2006 to 2009. 